\title{
Branch Update
}

\section{Kari Engele-Carter \\ President, CIPHI SK Branch}

Hello CIPHI members and Happy Winter!

It has been a busy fall and early winter as President of SK Branch. Our SK Branch Executive joined First Nations University of Saskatchewan, Environmental Health and Science students and Coordinator, Leanne Stricker, for a pizza night. Students received a presentation by SK Branch Communications and Advocacy Councilor, Kristin Waroma, on the benefits of a CIPHI membership. SK Branch Executive were able to network with new and continuing students of the program as well as receive an introduction to the new after degree program at First Nations University. SK Branch Executive continued with meetings on 14 and 15 September in Regina to discuss regular business of the Branch.

The 2016 National Annual Education Conference was held in Edmonton 25-28 September at Chateau Lacombe. The agenda included technical tours as well as multiple streams of lecture and fishbowl presentations. The National AGM was held on Monday 26 September. Four motions were passed to update the National Bylaws. The National Awards Luncheon was held on 28 September, as well as four National CIPHI Awards presented at the President's Banquet on 27 September. I was able to Co-Chair the National Awards presentations again this year with Sean O'Toole, NS/PEI President. Co-presenting National CIPHI Awards is a great honour and I appreciate the opportunity. Congratulations to all the award recipients.

Prior to the AGM, the National Executive Council held meetings on 23 and 24 September. On Saturday, 24 September we were able to participate in presentations with Garth Gosselin, BOC Chair; Keir Cordner, CoPE Chair; and Klaus
Seeger, EHFC Vice-Chair. As well, NEC, BOC, CoPE, and EHFC members joined for a networking lunch. CIPHI has a significant number of dedicated volunteers and I am most reminded of this during the annual meetings held before the Annual Education Conference (AEC). Please take the time to acknowledge CIPHI volunteers nationally, provincially, and locally. Thank you volunteers!

SK Branch was able to offer bursaries to 3 branch members to assist with attendance at the AEC. Over a dozen SK Branch members were able to attend the AEC and experience all that the AEC and Edmonton had to offer. Thank you to CIPHI Alberta Branch, Jason Macdonald and Phi Phan, Co-Chairs, and the Organizing Committee for a great event!

Environmental Public Health Week was celebrated throughout Saskatchewan 26-30 September. The Province of Saskatchewan proclaimed the week Environmental Public Health Week. This week is an excellent opportunity for EPHPs to acknowledge their significant contributions to public health across Canada. CIPHI SK Branch sponsored celebratory cakes for regional EPHP gatherings. Photos were submitted for our newsletter, The SK Branch Observer, and are posted on our webpage.

CIPHI SK Branch's 9th Annual Professional Education and Development Seminar was held in Saskatoon on 8 and 9 November. An excellent social and educational agenda was developed by the SK Branch Executive and led by PEDS Chair Michael McCann. The SK Branch AGM was held on 8 November.

Have you entered your PDHs for 2016? Entry can be completed at our Member Service Centre at www.ciphimember.ca. Follow us on facebook at CIPHI SASKATCHEWAN and on twitter@CIPHI_SK and visit our webpage at www.ciphi-sk.ca. 